\title{
セルオートマトンによる構造システムの自律的生成と最適化 AUTONOMOUS GENERATION AND OPTIMIZATION OF STRUCTURAL SYSTEMS BY CELLULAR AUTOMATON
}

\author{
三井和男* \\ Kazuo MITSUI
}

\begin{abstract}
This paper presents an effective method for designing structures using a cellular automaton, representing a simple conceptual basis for the self- organization of structural systems. The proposed methods are sufficiently simple to solve topology optimization problems as pure $0-1$ problems, and yet sufficiently complex to express a wide variety of complicated topolog ies. Local rules for the birth and death of cells are all that is required for this method, dependent on the type of desig $\mathrm{n}$ constraints, such as weight, stiffness and frequency. The effectiveness of the proposed method is demonstrated through numerical topology optimization problem examples. The method proposed in this paper offers a new approach to structural optimization, overcoming most of the problems associated with traditional techniques.
\end{abstract}

Keywords : self-organization, autonomous generation, cellular automaton, structural optimization 自己組織化，自律的生成，セルオートマトン，構造最適化

1.はじめに

構造の最適化問題は、大きさ、形状、トポロジーの3つの最適化 問題に分類できる。大きさを決定する最適化問題では、決定しなけ ればならない大きさそのものが設計変数となるため比較的少ない設 計変数で最適化問題を構成することができる。形状やトボロジーの 最適化問題でも設計変数のセットによって形状やトポロジーを定義 する場合がある。この場合、複雑な形状や種々のトポロジーを考虑 するためには設計変数の增加を避けることができない。そしてこれ らの設計変数は、最小重量のような、目的を達するために調整され ることになる。滑らかな最適設計問題は、設計変数の非線形方程式 系に䚻着し、勾配を用いた繰り返し計算によって解くことができる。 このような勾配を用いた数理計画手法によって最適化問題を解くた めには感度を計算する必要があり、目的関数と制約条件が設計変数 の陰関数となっているために、構造応答と感度がそれぞれの繰り返 しステップで数値的に決定される必要がある。したがって、設計変 数の増加にともなって最適化問題の複雑さも増加し、そのために、 設計変数の大きいセットをもつ最適化問題を勾配べースの数理計画 手法を使って解くことが難しくなる。

このような数理計画手法に起因する困難は、例えば、遺伝的アル
ゴリズムのようなヒューリスティックスを応用することによって克 服することができる。遺伝的アルゴリズムは、感度の計算を必要と しない探索・最適化の手法であり、生物進化のメカニズムに着想を 得た確率的探索の一手法である。感度を必要としない遺伝的アルゴ リズムは、アルゴリズムの柔軟性のために種々の最適化問題に適用 され、その有効性が様々な数值例を通して示されている。遺妘的ア ルゴリズムはランダムな突然変異と選択淘汰による選別にその基礎 をおいているが、一方、自然淘汰と共に重要な生物進化のメカニズ ムとして自己組織化があげられる。自然淘汰だけが生物の詳細な構 造を作り出したのではなく、もう一つの原動力としての自己組織化 というしくみによって、構造が自律的に発生したと考えられる ${ }^{1}$ 。 自己組織化を研究するための単純な数学モデルとしてセルオート マトン(CA)がある。セルオートマトンは、単純な要素(セル)の集合 によって構成されるシステムにおいて、セル間の局所的な相互作用 が挙動の複雑なパターンを自然に形成する、いわゆる自己組織化を 表現することができる。セルオートマトンは、均一な格子状のセル によって構成され、それぞれのセルは幾つかの状態をとることがで きる。そしてその状態は、それを取り巻いている若干の近傍セルの 状態のみに依存する局所的な規則に従って不連続の時間ステップで 
更新される。

多くの研究者がセルオートマトンの理論を使つて構造最適化問題 を研究している。連続体構造の位相最適化問題では、設計領域を応 力解析のための有限要素と同一のセルによって分割し、これらのセ ルの材料分布によって構造の形状と位相を記述することが多い。こ れらのセルの材料分布は状態とみなされ、最適化変数と考えること ができる。それぞれのセルでは、そのセルに材料が分布するか否か によって二つの可能な值、すなわち 0-1 の状態を考えることができ る。しかしながら、位相最適化問題のこのような定式化は一般に適 切問題ではなく、また凸計画問題とならない。そのために、この 0:1 整数計画問題は、連続的に変化する密度、ヤング率、あるいは板厚 での材料の記述を許して、連続な問題に置換されることが多い。セ ルオートマトンに基づく伊能 ${ }^{2)}$, 北 ${ }^{3)}$, 本間 ${ }^{4)}$ 等の研究は、それであ る。一方、Xie and Steaven ${ }^{5}$ の ESO 法は、連続体構造の位相最適化問 題を 0-1 問題として扱っている点で興味深い。この ESO 法を修正し て滑らかな境界形状を得ようとする大森等 のの方法も有効性が示さ れている。その他、Kikuchi 等の均質化設計法 ${ }^{7899)}$ は同種の問題にお いて多くの応用が試みられている。

本論では、構造システムの自己組織化のための単純なモデルとし て、セルオートマトンを用いて構造を最適化するための効率的な方 法を提案する。提案する方法は純粋な 0-1 の問題のまま位相最適化 問題を解く方法として、非常に単純であり、なおかつ多種多様な複 雑な位相と形状を表現するためには十分である。この方法では、セ ルの出現と消滅に関する局所的な規則だけが必要であり、設計感度 などを必要としない。このため、本手法は前述の数理計画手法を用 いた方法に起因する困難の大部分を克服し、構造最適化への新しい アプローチを提供する。

\section{2. セルオートマトンによる最適化手順}

本論において提案する CA を用いた最適化手法の基本的手順は、以 下に示す5つの内（3）（4）（5）を繰り返すものである。

（1）設計領域を均一な正方格子(セル)に分割する。

（2）設計領域に支持点と荷重点を含み、荷重を支持点まで伝達す る任意の構造システムを設定する。

（３）構造の応答を評価するために有限要素法を用いて応力解析を 行い、各セルの応力を求める。

(4)（3）で得られた応力をもとに、次の時間ステップにおけるセ ルの状態、すなわちそのセル上に材料が存在するか否かを決 定し、形状を更新する。

(5) (3) へ戻る。

ここで、設計領域を分割することによって得られる正方格子は、 セルオートマトンのセルとして、また有限要素解析の要素として用 いられる。また、（2）で設定する任意の構造システムとは、例えば Fig.1 のように支持点と荷重点を含んで荷重を支持点まで伝達でき るシステムである。さらに、各セルの応力は、等方性材料に対する 規準としてしばしば用いられる相当応力(von Mises stress)により評 価する。相当応力は次式で表される。

$$
\sigma=\sqrt{\sigma_{x}^{2}+\sigma_{y}^{2}-\sigma_{x} \sigma_{y}+3 \tau_{x y}^{2}}
$$

この相当応力を基に次の時間ステップにおける材料分布が決定す る。このとき、あるセル上に材料が存在するか否かを決定するのに、 そのセルの近傍だけに関連した局所的な規則が用いられるのがセル オートマトン法の特徵である。尚、ここでは、セルの中央における 相当応力を採用する。

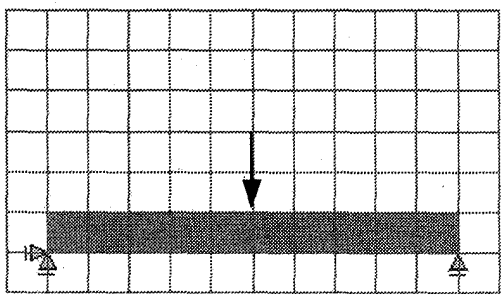

Fig.1 設計領域と正方格子

\section{3．セルの出現・消滅に関する局所規則}

設計領域中の各セル対して Fig.2 に示すような上下左右に隣接す る 4 つのセルを近傍とする Neumann 近傍を考える。上限応力値 $\sigma^{U}$ と下限応力值 $\sigma^{L}$ を予め設定し、相当応力が $\sigma$ を超えるセルが近傍に ある場合には Fig.2 に示すようにセルの值を 1 とし、そのセル上に 材料が出現するとした。また、相当応力がずを下回るセルは近傍の 応力にかかわらず Fig.3 のように值を 0 とし、そのセルから材料が 消滅するものとした。

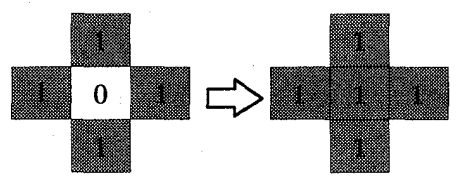

Fig.2 セルの出現

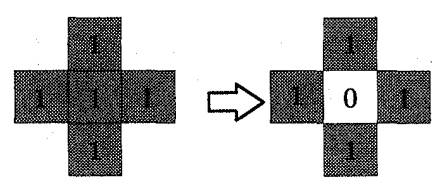

Fig.3 セルの消滅

\section{4. 最小重量問題への応用}

Fig.4 に示す $10 \mathrm{~m} \times 24 \mathrm{~m}$ の設計領域において壁面から $10 \mathrm{~m}$ の点に $800 \mathrm{~N}$ の荷重を支持する構造システムを上述の CA によって生成する ことを考える。これは構造最適化問題としてよく取り上げられる二 部材フレーム問題である。設計領域は $25 \times 60$ の正方格子で分割され、 初期形状を Fig.5(a)のような片持ち梁とした。応力解析には、正方 格子の 1 つを 4 節点平面応力要素とする有限要素法を用いた。尚、 使用する材料は、例えば鋼などの線形弾性材料とし、ヤング率とポ アソン比でその特性が記述できるものと仮定した。また、座屈など の発生は考慮しない。初期形状では、体積が $8 \times 10^{6} \mathrm{~mm}^{3}$ であり、最 終形状の $5.92 \times 10^{7} \mathrm{~mm}^{3}$ と比較して小さな構造であるが、応力は左側 の壁面付近で $31.8 \mathrm{Mpa}$ と右端近傍に比較して極めて高い值となって いる。このような初期形状では、非常に不均一な応力状態であるこ とがわかる。理想的には全ての部分において、ある安全な応力レべ ルの近傍に応力状態があることが望ましい。本研究で提案するセル 


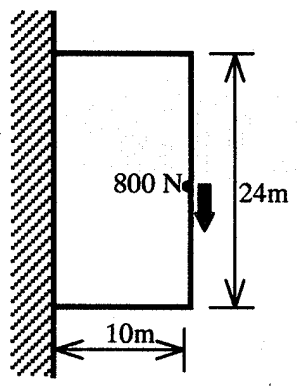

解析領域 : $25 \times 60$ セル ヤング率 : $100 \mathrm{GPa}$ ポアソン比 : 0.3

セルサイズ : $0.4 \mathrm{~m} \times 0.4 \mathrm{~m}$ セル厚 : $1.0 \mathrm{~mm}$ $\sigma^{U}=0.3 \mathrm{MPa}, \sigma^{L}=0.2 \mathrm{MPa}$

Fig.4 設計領域と荷重および支持条件

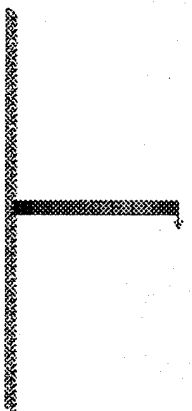

(a) Initial design

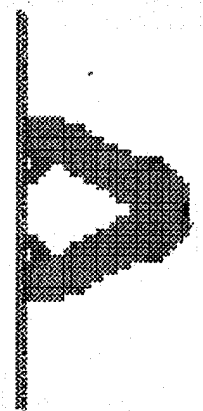

(b)

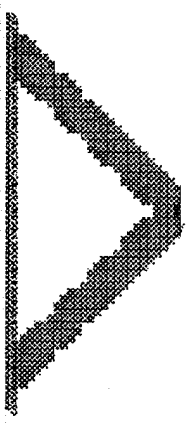

(c) Final result
Fig.5 二部材フレーム構造の生成 (1)

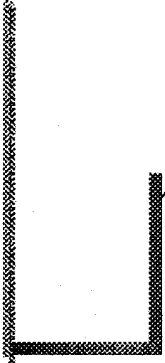

(a) Initial design

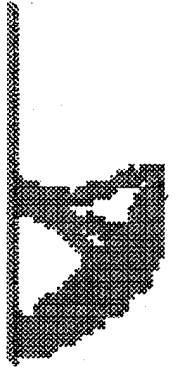

(b)

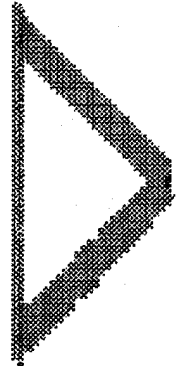

(c) Final result
Fig.6 二部材フレーム構造の生成（2）

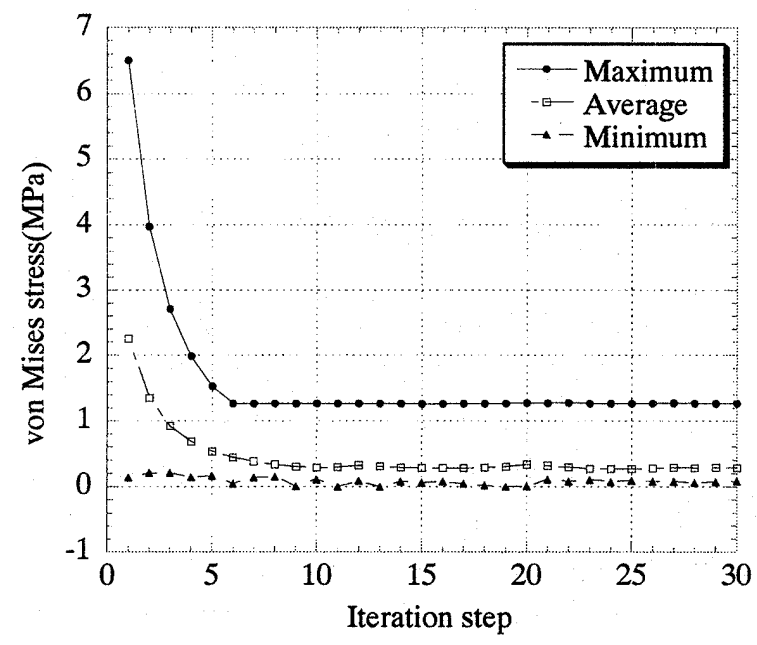

Fig.7 相当㐫力の推移
の出現と消滅の局所規則を適用すると、ステップを重ねるごとにセ ルが出現して梁せいが増大し、やがて(b)のように一本の梁が枝分か れし、30 ステップで解析解として知られる(c)のような二部材フレー 厶構造となる。Fig.7 は Fig.5 の生成過程における相当応力の推移で ある。本研究で用いるセルの出現と消滅に関する局所規則が、応力 の集中する荷重点などは別として、各セルの応力を均衡化し、その 平均值を、設定した上限値と下限値の間に誘導する働きをもつこと がわかる。尚、形態生成の過程では、孤立したセルや孤立したセル の集合が発生する場合があるが、これらのセルの応力は 0 となるた め、次ステップでこれらは消滅する。得られた形状では、高さと幅 の比がほぼ 2:1 となり、Xie 等 ${ }^{5)}$ の ESO 法による結果とも一致する。

Fig.6 は、同じ問題で初期形状を Fig.6(a)とした場合である。この場 合も Fig.5(c)と同様の二部材フレーム構造となる。

次に、Fig.8 に示す $10 \mathrm{~m} \times 5 \mathrm{~m}$ の設計領域を $50 \times 25$ のセルに分割し て、両端を支持して中央に荷重が作用する Michell タイプ構造の生 成を考える。ヤング率は $100 \mathrm{GPa}$ ，ポアソン比は 0.3 ，セ儿厚は $0.1 \mathrm{~m}$ である。荷重は $1000 \mathrm{~N}, \sigma^{y}=15 \mathrm{KPa}, \sigma^{L}=5 \mathrm{KPa}$ とした。Fig.9(a)は荷重 を支持点に伝達する初期形状である。(b)のように成長して 25 スッ テップで (c)のような Michell タイプ構造が得られた。

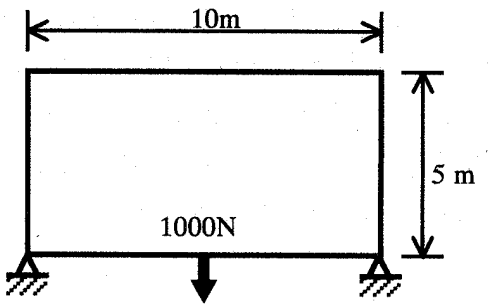

Fig.8 設計領域と荷重および支持条件

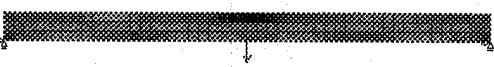

(a) Initial design

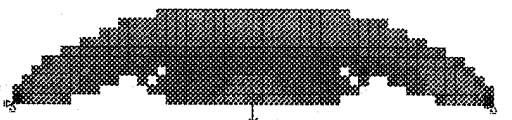

(b)

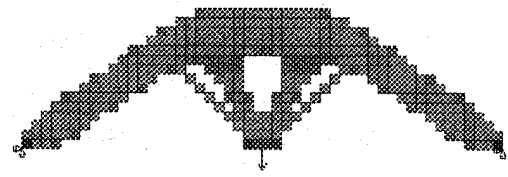

(c) Final result

Fig.9 Michell タイプ構造の生成

\section{5. 変位制約のある問題への応用}

Fig.10に示す片持ち梁を変位制約のある構造の最適設計問題の一 例として取り上げる。この構造も平面応力状態にあるとして、設計 領域を $80 \times 50$ の 4 節点平面応力要素で均等に分割する。板厚は $1 \mathrm{~mm}$ で、ヤング率は $207 \mathrm{GPa}$ 、ポアソン比は 0.3 であると仮定する。梁の 左端は固定され、右端中央に $3000 \mathrm{~N}$ の荷重が作用する。この荷重点 
における鉛直方向変位が $1 \mathrm{~mm}$ 以下で、体積が $5000 \mathrm{~mm}^{3}$ 以下となる 構造形態を探索する問題である。

この問題では、前述の相当応力の代わりに式(2)で与えられる平均 コンプライアンスを制御パラメターとして用いることができる。

$$
C=\frac{1}{2}\{P\}^{T}\{u\}
$$

ここで、 $\{P\}$ は節点荷重べクトル、 $\{u\}$ は節点変位ベクトルである。 i 番目のセル上の要素を除去することによって生じる平均コンプラ イアンスの増分(これを本論では要素平均コンプライアンスと呼ぶ) は、式(3)となる。

$$
\alpha_{i}=\frac{1}{2}\left\{u^{i}\right\}^{T}\left[k^{i}\right]\left\{u^{i}\right\}
$$

ここで、 $\left\{u^{i}\right\}$ は $i$ 番目のセル上の要素の要素変位ベクトル、 $\left[k^{j}\right]$ は 同じく要素剛性マトリクスである。前述の問題で述べたように相当 応力を制御パラメターとして用いる場合、本論で用いる局所規則は、 各セルの応力を均衡化し、その平均值を設定した上限値と下限值の 間に誘導する働きをもつ。この問題で平均コンプライアンスを制御 パラメターとして用いると、要素平均コンプライアンス $\alpha_{i}$ を均衡 化し、上限値 $\alpha^{U}$ および下限値 $\alpha^{L}$ の間に誘遒することが期待でき る。3000N の荷重が作用するとき、この荷重点における鉛直方向変 位が $1 \mathrm{~mm}$ であるとすると式（2）から C=1500 Nmm となり、このと き体積が $5000 \mathrm{~mm}^{3}$ の構造物で要素平均コンプライアンスが均衡化し ているとすると、 $\alpha_{i}$ の平均值は要素あたり $1.2 \mathrm{Nmm}$ となる。このこ とから要素平均コンプライアンス $\alpha_{i}$ の上限值 $\alpha^{U}$ および下限值 $\alpha^{L}$ は各々 $2.0 \mathrm{Nmm}, 0.4 \mathrm{Nmm}$ と設定した。

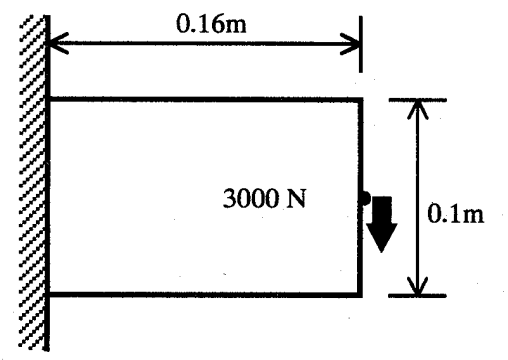

解析領域 : $80 \times 50$ セル ヤング率：207 GPa ポアソン比 : 0.3 セルサイズ : $2 \mathrm{~mm} \times 2 \mathrm{~mm}$ セル厚 : $1 \mathrm{~mm}$ $\alpha^{U}=2 \mathrm{Nmm}, \alpha^{\alpha}=0.4 \mathrm{Nmm}$

Fig.10 設計領域と荷重および支持条件

初期形状として、荷重を左端に伝達する任意形状の中から Fig.11(a)に示すように荷重点と支持点を結ぶ直線梁を選択した。 Fig.11(b)は途中形状であり、Fig.11(c)は最終的に得られた形状である。 Fig.12 は、構造の体積と荷重点の変位の変化を示したものである。 初期形状では、体積は $4480 \mathrm{~mm}^{3}$ で $5000 \mathrm{~mm}^{3}$ 以下であるが、変位は $11.0 \mathrm{~mm}$ であって制約条件を満たしていない。平均コンプライアン スを制御パラメターとして自律的に形状が変化し、それに伴って体 積や変位が変化する様子がわかる。体積は、8 ステップまでの初期 過程において徐々に増加し、これにより剛性も増加するために変位 は次第に減少する。8 ステップを過ぎて体積は減少するが、それで も変位は增加しない。これは、構造が自律的に形状を調節すること によって、別のトポロジーを獲得し、体積を減少しても剛性を低下 させない、むしろ剛性を増す形状となったためである。21 ステップ で目標とする解、荷重点における鉛直方向変位が $0.97 \mathrm{~mm}$ で、体積

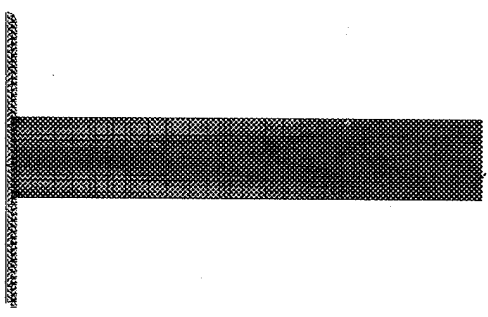

(a) Initial design

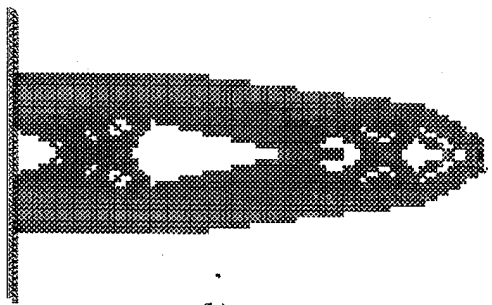

(b)

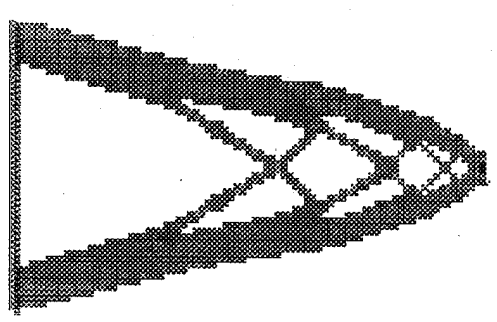

(c) Final result

Fig.11 変位制約のある片持ち梁構造の生成

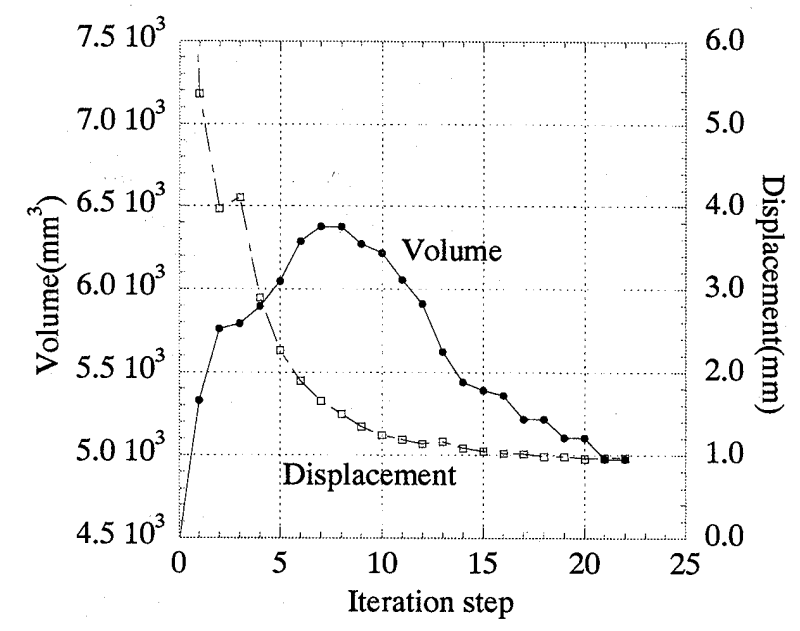

Fig.12 変位および体積の変化

が 4976 $\mathrm{mm}^{3}$ となる構造形態を見つけることができた。Fig.13 は、要 素平均コンプライアンス $\alpha_{i}$ の推移である。この場合も均衡化が見 られ、平均值がほぼ 1.2Nmm となったことがわかる。

MBB 梁構造と呼ばれる問題を Fig.14 に示す。設計領域を $20 \times 120$ の 4 節点平面応力要素で均等に分割する。板厚は $1 \mathrm{~mm}$ で、ヤング

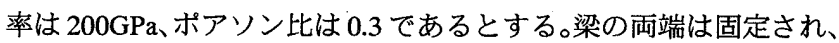
上部中央に $20000 \mathrm{~N}$ の荷重が作用する。この荷重点における鉛直方 向変位が $10 \mathrm{~mm}$ 以下で、体積が $480 \times 10^{3} \mathrm{~mm}^{3}$ 以下となる構造形態を 


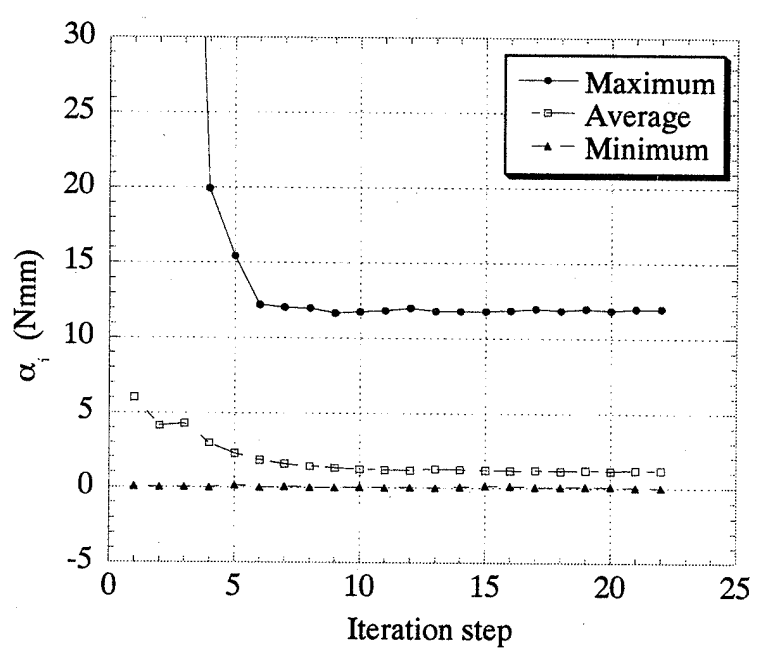

Fig.13 要素平均コンプライアンス $\alpha_{i}$ の推移

$20000 \mathrm{~N}$

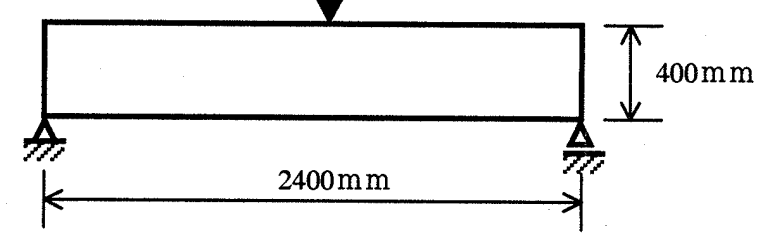

Fig.14 設計領域と荷重および支持条件

探索する問題とした。要素平均コンプライアンス $\alpha_{i}$ の上限値 $\alpha^{V}$ および下限值 $\alpha^{L}$ は各々 $90 \mathrm{Nmm}, 20 \mathrm{Nmm}$ と設定して、Fig.15(a)を 初期形状とすると、(b)(c)のように変化し、30 ステップで Fig.15(d) の形状を得ることができた。このとき、体積は $478.4 \times 10^{3} \mathrm{~mm}^{3}$ で、 変位は $9.79 \mathrm{~mm}$ である。

\section{6. まとめ}

セルの出現と消滅に関する単純な局所規則のみを定義することに よって、構造が自律的に発生するという自己組織化のもつ本質的な 能力を検証することができた。また、この手法を構造システムの形 態生成に適用し、形状最適化問題に対する有効性を示すことができ た。非常に単純なアルゴリズムをもつ本手法はここに示した最小重 量問題や変位制約のある問題のみならず、振動数に関する最適化問 題にも応用することが可能である。しかしながら、上限応力值 $\sigma^{y}$ と 下限応力値 $\sigma^{L}$ の設定や要素平均コンプライアンスの上限値 $\alpha^{U}$ と 下限値 $\alpha^{L}$ の設定は、解の精度に影響を与える場合もあり、また初 期形状によって、得られる形態に差異が生じる場合もある。これら の制御パラメー夕を合理的に設定する方法や、局所解からの脱出の 方法など研究しなければならない問題も多く残される。安定的に解 の探索の精度を向上することが今後の課題である。

\section{参考文献}

1）チュアート・カウフマン:自己組織化と進化の理論, 日本経済新聞社, 1999

2）伊能教夫他:力学構造物を自己組織化するセルオートマトン, 日本機械学 会論文集(A 編),Vol.61,No.586, pp.1416-1422, 1995

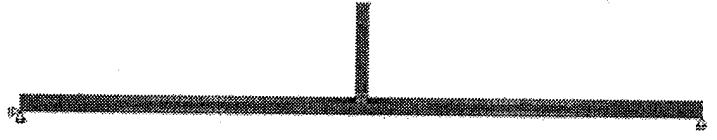

(a) Initial design

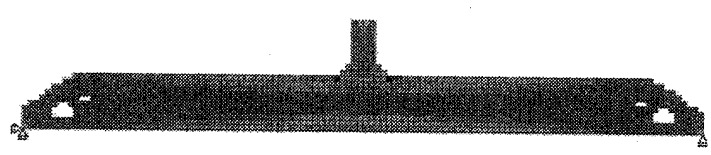

(b)

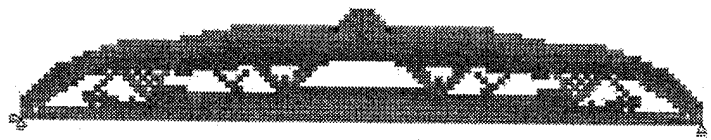

(c)

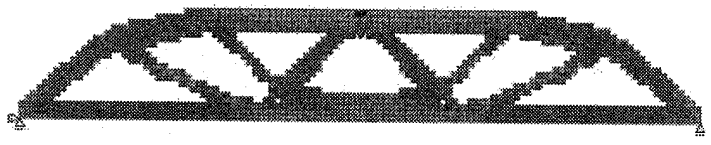

(d) Final result

Fig.15 MBB 梁構造の生成

3) 北栄輔他：CA の構造物設計への応用, 計算工学講演会 論文集,Vol.3, pp.601-604,1998

4) 本間俊男, 登坂宣好, 角広幸 : 自律分散アプローチによる逆問題の計算 法, 日本建築学会構造系論文集, 第 526 号, pp.69-76, 1999 年 12 月

5) Xie, Y.M. and Steven, G.P. : Evolutionary Structural Optimization, Spronger-Verlag, 1997

6) 大森博司, 崔昌禹他 : 等㐫力線を導入した ESO 法による構造形態の創生 (その 1-3), 日本建築学会大会学術講演梗概集, pp.349-354, 2000

7) Bendsoe, M.P. and Kikuchi, N. : Generating Optimal Topologies in Structural Design using a Homogenization Method, Computer Methods in Applied Mechanics and Engineering, Vol.71, pp.197-224, 1988

8) Suzuki, K. and Kikuchi, N. : A homogenization method for shape and topology optimization, Computer Methods in Applied Mechanics and Engineering, Vol.93,pp.291-318, 1991

9) 藤井大地, 江島晋, 菊池昇 : 均質化設計法を用いた弾性変形機構の位相 最適化, 日本建築学会構造系論文集, 第 528 号,pp.99-105, 2000 年 2 月

10) 三井和男, 大久保雅司, 登坂宣好 : 構造システムの自律的生成, 計算工 学講演論文集, Vol.5, pp.85-86, 2000

11) 三井和男, 大久保雅司, 登坂宣好 : 構造システムの自律的生成, 日本建 築学会大会学術講演梗概集, pp.343-344, 2000

12）三井和男, 登坂宣好: セル・オートマトンによる構造形態の自律的生成, 日本応用数理学会 2000 年度会講演予稿集, pp.90-91, 2000

（2001年 9 月 3 日原稿受理， 2002 年 1 月 22 日採用決定） 